\title{
TEACHING ENGLISH FOR NURSING BY USING TASK-BASED LANGUAGE TEACHING
}

\author{
Ahmad Kailani ${ }^{1}$, Tenny Murtiningsih ${ }^{2}$ \\ (ahmadikay@gmail.com, tennymahatma@gmail.com) \\ Universitas Muhammadiyah Banjarmasin, Indonesia.
}

\begin{abstract}
English for nursing is one of the branches of English for Specific Purposes. This type of English lesson requires the teacher to choose a specific method in order to meet a specific learning objective. The final goal of learning this kind of English is to equip learners with competencies that suit their future job, one of them, is English skill. This is inseparable from the choice of an appropriate teaching method by the teacher. Many studies on the implementation of specific teaching methods have been undertaken. However, little is still known about the students' responses to the implementation of Task-Based Language Instruction in English for Nursing Classes. To fill this gap, the current study shed a light on this matter. This qualitative research aimed to explore students' perception of this teaching method. There were 58 nursing students invited as the respondents. The data were garnered through interview and questionnaires. The implication of this research is to be contributed to the field of EFL teaching methodology as the expansion for the current studies in English for specific Purposes field.
\end{abstract}

Keywords: Task-Based Language Teaching, English for Professional Purposes, English for Nursing, qualitative study.

\section{INTRODUCTION}

Over the last two decades, the focus of teaching English is on the communicative ability. This has made the communicative language teaching approach popular since its emergence in the early 1980s. One of the popular teaching methods under this communicative approach is Task-Based Language Teaching (TBLT). This method has been proved compatible with learner-centered classroom interaction (Ellis, 2003; Nunan, 2005; Richards \& Rodgers, 2001). TBLT is made up of components such as goal, procedures, and specific learning target. (Murphy, 2003; Nunan, 2004; Skehan, 1998); It also gives more emphasis on learning activities that takes a bigger portion of the content rather than linguistic items (Beglar \& Hunt, 2002; Carless, 2002; Littlewood, 2004). 
In the context of Second Language Acquisition (SLA), a complex interaction is made through a complex interconnection among materials, activities, and evaluative feedback. Essentially, TBLT has given positive impacts on these variables. This means that TBLT facilitates learners with natural sources of the meaningful content, supportive atmosphere and supportive response that afford more opportunities for students to use the language, especially in the context of Asian EFL classroom where learners do not have sufficient time to use the targeted language on daily interaction. More exposures are needed for allowing learners to express out their target language. In his interviews based study, with teachers, teacher educators, and ministry officials, Nunan (2003) indicates that TBLT emerged as a central concept by teachers, teacher educators, and ministry.

However, it is still little known the responses of students towards the use of TBLT in EFL classes. To fill this void, this study is aimed to explore EFL students' perceptions of task-based instruction based on investigating the use of simulation teaching technique in English for nursing class. This will provide insight for teachers to design and implement any real communicative tasks, which are critically important for EFL learners to experience meaningful language use. It will also contribute to facilitating EFL teachers' practical use of TBLT techniques, thereby improving the learners' communicative abilities.

In the context of pedagogy, ESP courses are designed to fulfil professional and academic communication needs. The main objective is to enable learners to communicate in English mediated professional setting. Johns (2013) argues that ESP has been researched since its emergence in the 1960s. Furthermore, he explained that there have been theories, concepts, approaches, and analytical tools used to assess ESP courses. Some of them are content-based instruction (CBI), genre-based instruction, the New Rhetoric, and Task-Based Language Teaching (TBLT). Hutchinson and Waters (1987) contend that ESP can be viewed as an approach for language teaching to meet specific learning needs. This specialization makes ESP different from other English course in terms of its disciplinary knowledge and context (Fang, 2006).

Dudley-Evans and St. John (1998) define ESP characteristics as follow:

1. ESP courses are designed to meet discipline-specific learning goals with a different level of proficiency.

2. It is informed by a specific approach with specific instructional design.

3. The learning materials and methods are developed or adapted for responsive instruction.

4. ESP courses involve discipline-specific knowledge, genres, discourses, and specific context.

5. In the ESP course, students gain knowledge or concepts from their specialization.

6. It requires students to have knowledge about specific genres and sub-genres in which the language itself operates. 
Basturkmen (2010) categorizes the different ESP branches as follows:

\begin{tabular}{|l|lr|l|}
\hline Branches & \multicolumn{2}{|l|}{ Sub branches } & Examples \\
\hline $\begin{array}{l}\text { English for } \\
\text { academic } \\
\text { purposes }\end{array}$ & $\begin{array}{l}\text { English for general academic } \\
\text { purposes } \\
\text { English for specific academic } \\
\text { purposes }\end{array}$ & $\begin{array}{l}\text { English for academic } \\
\text { writing } \\
\text { English for law }\end{array}$ \\
\hline $\begin{array}{l}\text { English for } \\
\text { professional } \\
\text { purposes }\end{array}$ & $\begin{array}{l}\text { English for } \\
\text { professional purposes } \\
\text { English for } \\
\text { professional purposes }\end{array}$ & $\begin{array}{l}\text { English for the health } \\
\text { care sector } \\
\text { English for nursing }\end{array}$ \\
\hline $\begin{array}{l}\text { English for for } \\
\text { occupational } \\
\text { purposes }\end{array}$ & $\begin{array}{l}\text { English feneral for } \\
\text { occupational purposes } \\
\text { English for } \\
\text { occupational purposes }\end{array}$ & $\begin{array}{l}\text { English focific the } \\
\text { hospitality industry } \\
\text { English for hotel } \\
\text { receptionist }\end{array}$ \\
\hline
\end{tabular}

Within this current study context, we explore the implementation of TBLT in English for nursing context, which is under the sub-branches English for specific professional purposes.

Many studies have been conducted to look at the implementation of Task-Based Language teaching in the ESP field. Shabani \& Ghasemi (2014) have found that TBLT is a more effective approach compared to Content-Based Instruction in terms of teaching reading comprehension. The research was undertaken at a university in Iran. There were two groups of students chosen, each consisted of thirty participants. The groups were divided into two categories; one controlled group (using content-based instruction) and another one is the experimental group (using task-based language teaching). The findings indicate that the experimental group performed better in the ESP reading class than that of the content-based instruction group.

Another research on the effectiveness of task-based language teaching was done by Sarani \& Sahebi (2012). They investigated the teaching of vocabulary in ESP courses within the paradigm of task-based language teaching. The results show that task-based language teaching is more effective in teaching technical vocabularies compared to the traditional one. Another study on the implementation of TBLT in ESP was undertaken by Rahman (2010) about the applications of the task-based approach to teaching oral communication skills in an Indian University. The tasks used had given an interesting learning atmosphere for the students. They got involved in the task because the tasks were giving the feeling of a real-life situation. Their final performances were impressively polished and much improved. This was indicated by 70 per cent of the students got $\mathrm{A}$ at the final exam. 


\section{METHOD}

\section{Research Questions}

In an attempt to investigate the use of task-based language teaching in teaching English for nursing, these three questions were posed to answer research problems:

1. What are learners' views on the use of simulation techniques in teaching English for nursing?

2. How well does task-based language teaching, in this context, simulation technique, support learners to master English for Nursing?

3. What is the most important skill needed to improve if this simulation technique is used in English for nursing class?

\section{The Participants}

The participants of the research are 53 nurse students taking English for Nursing course. The participants were in the sixth semester when they were invited to join in this research. The reason for choosing this criterion is that because they already took Nursing English $1 \& 2$ classes. Therefore, this study is intended to compare the previous lessons they got using other teaching methods and the current English for Nursing class that is treated by task-based language teaching, particularly the use of the simulation technique.

\section{Data Collection}

The data were garnered through survey and interview. Fifty-three questionnaires were administered to know students' perception on the use of TBLT in English for Nursing class and one in-depth interview was undertaken to investigate student's perception of this method.

\section{FINDINGS AND DISCUSSIONS}

\section{Analysis Results}

1. What are learners' views on the use of simulation techniques in teaching English for nursing?

Table 1. Distribution of survey results (Questionn 1)

\begin{tabular}{|c|c|c|c|c|c|}
\hline \multirow{2}{*}{$\begin{array}{c}\text { Question } \\
\text { no. }\end{array}$} & \multicolumn{4}{|c|}{ Option } & Total frequency per item \\
\hline & $\mathrm{A}$ & $\mathrm{B}$ & $\mathrm{C}$ & $\mathrm{D}$ & TOTAL \\
\hline 1 & 22 & 3 & 23 & 5 & 53 \\
\hline
\end{tabular}




\section{Note:}

Option A: the use of simulation technique would be challenging and I will try it Option B: that would be easy for me

Option C: it would be difficult since I have problems speaking English Option D: it would be very difficult because I do not like English.

From the table 1, it is clearly seen that the majority of respondents perceived that the use of TBLT, in this context simulation, would be difficult for them (23 responses out of 52) due to their speaking ability. However, the respondents still have the motivation to learn even though this would be challenging for them ( 22 responses out of 52).

2. How well does task-based language teaching, in this context, simulation technique, support learners to master English for Nursing?

Table 2. Distribution of survey results (Question 2)

\begin{tabular}{|c|c|c|c|c|c|}
\hline \multirow{2}{*}{ Question no. } & \multicolumn{4}{|c|}{ Option } & Total frequency per item \\
\hline & $\mathrm{A}$ & $\mathrm{B}$ & $\mathrm{C}$ & $\mathrm{D}$ & TOTAL \\
\hline 2 & 31 & 6 & 5 & 11 & 53 \\
\hline
\end{tabular}

\section{Note:}

Option A: Simulation would help me improve my communicative competence Option B: I do not have any clue Option C: I am not sure

Option D: maybe it would help me

We can see from the data, students dominantly perceive that simulation technique would help them improve their communicative skill (31 responses out of 52)

3. The most important skill needed to improve this simulation technique is used in English for nursing class.

Table 3. Distribution of survey results (Question 3)

\begin{tabular}{|c|c|c|c|c|c|}
\hline \multirow{2}{*}{ Question no. } & \multicolumn{4}{|c|}{ Option } & Total frequency per item \\
\hline & $\mathrm{A}$ & B & $\mathrm{C}$ & $\mathrm{D}$ & TOTAL \\
\hline 3 & 9 & 42 & 0 & 2 & 53 \\
\hline
\end{tabular}

\section{Note:}

Option A: listening

Option B: speaking

Option C: reading

Option D: writing 
The data depict that dominantly the respondents think that speaking skill is the most essential skill to develop (42 responses out of 52).

From the quantitative data above, we can see that the use of TBLT is a supportive teaching method for nurse students even though this method would be challenging for them since this is a new teaching method for them.

In the same vein, the interview results indicate that all students accept this method as a teaching method for English for nursing class. One of the participants said:" This method helps, sir". Especially, when we perform clinical attachment we can teach our colleagues English. This may build up our self-confidence". The participants explicitly give a positive evaluation of this method.

\section{CONCLUSION AND SUGGESTIONS}

Task-based language teaching, within this context, the use of simulation for teaching nursing English, has been perceived as an engaging way for nurse students to study English. Although the method was used in the class, the challenges still remain unsolved. Limited time allocation for teachers to prepare the material as well as for students to do the entire stages of simulation, students' language proficiency, and learning motivation are among issues that need to be taken into account for future implementation.

Future study in the same field needs to be undertaken in order to deeply investigate the implementation of the task-based language teaching in ESP context. The current study just used questionnaire and structured interview for data collection. There is a need to employ other methods of data collection to enrich the findings.

\section{REFERENCES}

Basturkmen, H. (2010). Developing courses in English for specific purposes. Springer.

Carless, D. (2004). Issues in teachers' reinterpretation of a task-based innovation in primary schools. TESOL Quarterly, 38(4), 639-662.

Ellis, R. (2003). Task-Based Language Learning and Teaching. Oxford University Press.

Fang, Z. (2006). The language demands of science reading in middle school. International Journal of Science Education, 28(5), 491-520. 
Hunt, A., \& Beglar, D. (2002). Current research and practice in teaching vocabulary. Methodology in language teaching: An anthology of current practice, 258-266.

Johns, A. M. (2013). The history of English for specific purposes research. The handbook of English for specific purposes, 5, 30.

Johns, A. M., \& DUDLEY-EVANS, T. O. N. Y. (1998). English for specific purposes: International in scope, specific in purpose. TESOL Quarterly, 25(2), 297-314.

Littlewood, W. (2004). The task-based approach: Some questions and suggestions. ELT Journal, 58(4), 319-326.

Murphy, J. (2003). Task-based learning: the interaction between tasks and learners. ELT Journal, 57(4), 352-360.

Nunan, D. (2003). The impact of English as a global language on educational policies and practices in the Asia-Pacific Region. TESOL Quarterly, 37(4), 589-613.

Nunan, D. (2004). Task-based language teaching. Ernst Klett Sprachen.

Nunan, D. (2005). Important tasks of English education: Asia-wide and beyond. Asian EFL Journal, 7(3), 5-8.

Rahman, M. M. (2010). Teaching oral communication skills: A task-based approach. ESP World, 9(1), 1-11.

Richards, J. C., \& Rodgers, T. S. (2001). Approaches and methods in language teaching. Cambridge university press.

Shabani, M. B., \& Ghasemi, A. (2014). The effect of task-based language teaching (TBLT) and content-based language teaching (CBLT) on the Iranian intermediate ESP learners' reading comprehension. Procedia-Social and Behavioral Sciences, 98, 1713-1721.

Sarani, A., \& Sahebi, L. F. (2012). The Impact of Task-Based Approach on Vocabulary Learning in ESP Courses. English Language Teaching, 5(10), 118-128.

Shabani, M. B., \& Ghasemi, A. (2014). The effect of task-based language teaching $(T B L T)$ and content-based language teaching (CBLT) on the Iranian intermediate ESP learners' reading comprehension. Procedia-Social and Behavioral Sciences, 98, 1713-1721.

Skehan, P. (1998). A framework for the implementation of task-based instruction. Applied linguistics, 17(1), 38-62. 


\section{APPENDICES}

Appendix 1

Questionnaire recapitulation

\begin{tabular}{|c|c|c|c|c|c|}
\hline \multirow{2}{*}{$\begin{array}{c}\text { SOAL } \\
\text { NO. }\end{array}$} & \multicolumn{4}{|c|}{ FREKUENSI OPSI JAWABAN } & \multirow{2}{*}{$\begin{array}{c}\text { TOTAL } \\
\text { JAWABAN }\end{array}$} \\
\hline & $\mathbf{A}$ & B & $\mathbf{C}$ & $\mathbf{D}$ & \\
\hline 1 & 14 & 26 & 12 & 1 & 53 \\
\hline 2 & 26 & 26 & $\mathbf{0}$ & 1 & 53 \\
\hline 3 & 45 & $\mathbf{0}$ & 1 & 6 & 52 \\
\hline 4 & 1 & 9 & $\mathbf{0}$ & 43 & 53 \\
\hline 5 & 47 & $\mathbf{0}$ & 5 & 1 & 53 \\
\hline 6 & 15 & 23 & 9 & 6 & 53 \\
\hline 7 & 18 & 3 & 1 & 31 & 53 \\
\hline 8 & 16 & 11 & 5 & 20 & 52 \\
\hline 9 & 2 & 47 & 1 & 3 & 53 \\
\hline 10 & 4 & 46 & 1 & 2 & 53 \\
\hline 11 & 43 & 2 & 7 & 1 & 53 \\
\hline 12 & 37 & 2 & 12 & 2 & 53 \\
\hline 13 & 14 & 36 & 0 & 1 & 51 \\
\hline 14 & 46 & 2 & 5 & 0 & 49 \\
\hline 15 & 25 & 15 & 8 & 4 & 52 \\
\hline 16 & 42 & 1 & 8 & 2 & 53 \\
\hline 17 & 41 & 2 & 9 & 1 & 53 \\
\hline 18 & 22 & 2 & 23 & 5 & 52 \\
\hline 19 & 9 & 42 & 0 & 1 & 52 \\
\hline 20 & 31 & 5 & 5 & 11 & 52 \\
\hline
\end{tabular}




\section{Appendix 2 \\ Interview results}

This is the original result of transcript, this transcript was then translated into English for the purpose of data analysis

\section{Interview 1}

A: Assalamu'alaikum Warahmatullahi Wabarakatuh

B: Wa'alaikumsalam Warahmatullahi Wabarakatuh

A: Oke, sebelumnya responden dalam riset kami yang berjudul " Pengembangan Materi Ajar Bahasa Inggris Menggunakan Teknik Simulasi Untuk Mahasiswa S1 Keperawatan". Sebelumnya, boleh saya tau siapa nama lengkap ibu? saya ucapkan terima kasih karena telah bersedia menjadi

B: Nama saya Esmi Anggriani

A: Oke, Ibu mengajar di prodi apa bu?

B: S1 Keperawatan

A: Di S1 Keperawatan itu bahasa inggris yang diajarkan itu, eh maaf ada ga bahasa inggris disana?

B: Ada

A: Ada, Sebagai mata kuliah umum atau mata kuliah apa namanya, tambahan gitu?

B: Mata kuliah umum

A: Mata kuliah umum ya?

B: Inggih

A: Oke, kita mengenal dua gitu kan jenis bahasa inggris, ada General English sama English For Specific Purposes. Nah kira-kira kalo yang di keperawatan masuk yang mana ini kategorinya? Apakah General English atau English For Specific Purposes?

B: Kayaknya tergantung semesternya pa

A: Oke

B: Kalo yang di semester satu atau dua itu general English

A: Oke

B: Inggih

A: Terus

B: Kalo yang ke atasnya itu sudah arahnya ke keperawatannya

A: Berarti English For Specific Purposes ya

B: Oke, kalo menurut ibu nih kira-kira bagaimana sih cara meningkatkan kemampuan komunikasi bahasa inggris mahasiswa itu?

A: Banyak sih pa, yang jelas itu pastinya simulasi dari pengajarnya

B: Oke

A: Ya

B: Ada yang makanya ada yang melalui listening, speaking, reading itulah mungkin yang bisa mengembangkan mahasiswa. Jadi, apa-apa yang lemah dari mahasiswa itu yang perlu kita tingkatkan. 
A: Oke, berarti ibu sudah mengenal metode simulasi ya bu?

B: Inggih

A: Oke, nah kalau secara umum nih, mata kuliah apa saja sih yang menggunakan metode simulasi di keperawatan, mata kuliahnya?

B: Di luar dari bahasa inggris?

A: Iya

B: Kalo di bahasa inggris sudah pasti ya pa ya, simulasi itu penting. Kemudian juga, mata kuliah seperti keperawatan medical bedah, itu kan perlu demonstrasi untuk tindakannya, kemudian keperawatan dasar, kemudian keperawatan maternitas, anak, gerontik, hampir semua mata kuliah keperawatan yang terspesialisasi dari keperawatan itu perlu untuk simulasi

A: Oke, Nah tentunya dalam simulasi kan kita perlu yang namanya SOP ya bu ya?

B: Inggih

A: Nah, oke kira-kira seberapa penting SOP itu kalo menurut ibu dalam metode simulasi ini bu?

B: Pastinya sangat penting ya pa ya, karena itu menjadi gate line bagi mahasiswa dan pengajar agar jangan sampai terjadi mis komunikasi, mis persepsi, dengan langkahlangkah yang harus dilakukan oleh mahasiswa, jadi itu, menurut saya sebagai gate line nya

A: Berarti, simulasi ini harus sesuai ya dengan SOP?

B: Iya

A: Oke, menurut ibu nih, sekarang apakah simulasi itu meningkatkan kemampuan komunikasi mahasiswa?

B: Iya, jadi simulasi ini kan anggapannya sebagai stimulus. Jadi, dari stimulus itulah nanti yang membuat mahasiswa itu berespon sesuai dengan apa yang kita berikan simulasi, jadi dari situ memang pastinya memang meningkatkan komunikasi, meningkatkan skill, meningkatkan segala macam analisis thinking nya.

A: Oke, sekarang pendapat ibu nih, jika simulasi tersebut kita terapkan di dalam kelas bahasa inggris, kira-kira seperti apa itu bu pendapatnya aja?

B: Sebelumnya saya ingin bertanya, simulasinya ini apakah simulasi perindividu atau perkelompok pa?

A: Ya, keduanya. Dalam proses pengajaran, kadang mungkin ada aktivitas pembelajaran yang memerlukan berpasangan, berkelompok atau mungkin cukup satu orang saja melakukan simulasi. Kira-kira seperti apa itu bu pentingnya ini?

B: Kalau menurut saya memang perlu ya pa ya, karena kalo kita hanya belajar, ceramah, tanya jawab, kita belum tentu bisa melihat semua mahasiswa itu bagaimana output ataupun proses yang kita lihat ketika proses belajar mengajar. Tapi, kalo dengan metode simulasi, sedikit banyaknya kita melihat bagaimana masing-masing individu itu perkembangannya.

A: Oke, terus apakah dengan menggunakan simulasi berbahasa inggris ini dapat meningkatkan fluensi mereka dalam berbahasa inggris? 
B: Menurut saya, sangat efektif karena dari situ juga nanti muncul mungkin kepercayaan diri mereka yang awalnya tidak berani karena memang harus wajib, akhirnya dia mengeluarkan skill nya itu.

A: Pernahkah ibu menerapkannya ini?

B: Pernah

A: Dan fluensi mereka meningkat?

B: Inggih

A: Oke

B: Salah satunya kan kaya roleplay ya pa ya, nah disitu juga mahasiswa yang awalnya tidak bisa berbahasa inggris minimal dia menghafalkan dialog-dialog dia itu kan juga sudah mulai membuat dia percaya diri tampil dihadapan teman-temannya, bagaimana pronunciation nya itu juga.

A: Oke, terakhir nih bu, kira-kira saran ibu nih untuk penerapan metode ini kedepannya seperti apa, metode simulasi ini?

B: Metode simulasi kalau untuk mahasiswa keperawatan salah satunya itu S1 keperawatan itu mahasiswanya kan banyak ya pa ya, kalau menurut saya kalo simulasi ini hanya dilakukan oleh satu pengajar ketika di kelas itu memakan waktu yang banyak terutama karena di S1 Keperawatan jumlah mahasiswanya banyak. Jadi mungkin perlunya fasilitator, itu. Kemudian juga, karena mahasiswanya itu banyak, jadi mungkin juga setiap pertemuan mungkin simulasinya berbeda-beda, jadi tidak hanya monoton simulasi seperti itu terus mungkin ada variatifnya. Kemudian, simulasinya tidak hanya dari segi misalnya pengembangan speakingnya saja, tapi bisa listening nya kah, reading nya kah, dan lain sebagainya.

A: Semua skill bu ya?

B: Inggih

A: Oke, ada lagi kah yang mau ditambahkan?

B: Tidak ada

A: Tidak ada? Oke, terima kasih Ibu Esmi atas waktunya dan sekali lagi kami memohon konfirmasi izin nanti data ini akan kami pakai di dalam penelitian kami, dan akan di desiminasikan dalam bentuk hasil atau laporan penelitian. Apakah ibu bersedia?

B: Inggih

A: Oke, terima kasih dan selamat siang

B: Oke

A: Assalamu'alaikum warahmatullahi wabarakatuh

B: Wa'alaikumussalam pa

\section{Interview 2}

Mr. Key : Assalamualaikum Warahmatullah hiwabarakatuh, selamat siang.

Narasumber : wa'alaikumsalam selamat siang.. 
Mr. Key : Nama saya Kailani saya anak team riset balai Universitas Muhammadiyah Banjarmasin. Saya bersama team akan melakukan riset tentang penggunaan simulasi.

Narasumber : iya...

Mr. Key : dalam pengajaran Bahasa Inggris di prodi S1 Keperawatan, eeee sebelumnya saya ucap kan terimakasih kepada mas yang telah bersedia untuk eeee memenuhi undangan kami sebagai respon dan wawancara ini.

Narasumber : iya.

Mr. Key : kira-kira menurut mas nih, penguasan Bahasa Inggris itu penting nggak dalam pekerjaan nantinya setelah lulusan dari kampus ini.

Nara Sumber : penting karena beberapa perusahaan atau rumah sakit tu ada yang eeeee syarat nya itu bisa berbahasa inggris, Jadi memudahkan lah.

Mr. Key : oke, na kira-kira nih lebih spesifik nya lagi bisa tidak mas khair jelaskan kenapa sih penguasaan bahasa.... (terputus)

\section{Interview 3}

Mam T : Assalamualaikum

Narasumber : Wa'alaikumsalam

Mam T : iya.. saya sedanga mengadakan penelitian terkait dengan penggunaan buku materi Bahasa Inggris, dengan menggunakan teknik simulasi, terima kasih sudah bersedia menjadi responden kami.

Narasumber : sama-sama

Mam T : iyaa, menurut mba apakah penggunaan bahasa inggris itu penting ya untuk kamu nanti kalo bekerja.

Narasumber : hooh penting banget bu.

Mam T : oh penting banget ya... kalu gitu jelaskan sih bagaimana pentingnya bahasa inggris nantinya buat kerja kamu?

Narasumber : yang pertama gini kan bu ya...kalu apalagi di dunia keperawatan sendiri terkhususnya di Indonesia itu susah nyari kerja untuk dunia keperawatan eee menambah peluang besar bagi kita kalu misalnya kita dalam keperawatan ini bisa mengaplikasikan bahasa inggris ini apalagi kalu nyari pekerjaan diluar negri seperti itu.

Mam $\mathrm{T}$ : mba pengen kerja diluar negri ?

Narasumber : iya

Mam $\mathrm{T}$ : oo iya bagus betul - betul ya ... ee di keperawatan sendiri mengenal nggak dengan simulasi

Narasumber : iya

Mam $\mathrm{T} \quad$ : iya... contohnya dipakai di metode apa ? 
Narasumber : ee simulasi itu biasanya untuk pengajaran gimana sih pengaplikasian di dunia kerjaan nantinya bu... misalnya kita belajar menginfus berlajar mencek tekanan darah segala macam gitu

Mam T : oo itu diajarkan di keperawatan dengan metode simulasi ?

Narasumber : iya

Mam T : oo iya dmna itu waktu mempraktikannya...dikelas ?

Narasumber : oo itu dikelas bisa diruangan labolatorium......

(Selesai)

\section{Rekaman selanjutnya}

Mam T : : :

Narasumber : Waalaikumussalam

Mam T : iya saya sedang mengadakan penelitian menggunakan tekhnik simulasi dalam pengajaran keperawatan jadi kaya nursing english gitu ya ?

Narasumber : iya

Mam T : apakah mba sudah belajar mengenai simulasi keperawatan di kuliahnya?

Narasumber : iya sudah

Mam $\mathrm{T} \quad$ :sudah ya.... mba belajar bahasa inggris mulai kelas berapa?

Narasumber : mulai belajar bahasa inggris itu sih mulai SD SMP SMA itu sudah mulai belajar bahasa inggris dasar - dasarnya.

Mam T : Menurut mba bahasa inggris itu penting nggak untuk keperawatan nantinya bekerja ?

Narasumber $\quad:$ (Terputus) 